Neuvostoliitossa "ei ollut sosialismia eikä neuvostojen valtaa, kuten historioitsija Osmo Jussila on todennut".

Ropponen ja Sutinen kartoittavat neuvostoleirejä laajalla säteellä Vienanmereltä Kolymaan, Karagandasta Vorkutaan. Kuvitus on paitsi runsasta myös laadukasta, vain matkamiesten kiertueita havainnollistava kartta puuttuu. Alan keskeinen kirjallisuus on luettu ja nivelletty historiajaksoihin, joissa huomioidaan keisarillisen Venäjän pakkotyöjärjestelmä ilman että se samastettaisiin vuoden 1917 jälkeisiin leireihin. Kirjalistasta uupuu ainoastaan yksi perusteos, puolalaisen Tomasz Kiznyn monumentaalinen matka- ja kuvakirja Gulag, joka ilmestyi 2000-luvun alussa lukuisina laitoksina.

Kiznyn jäljissä kulkevilla suomalaisilla on ajan tuomaa lisäperspektiiviä pohdintoihinsa. Valtioterrorin perinnöstä puhutaan suorastaan oppinein sanankääntein, ja paikallisten kanssa käydyt keskustelut ovat nekin erinomaisen valaisevia. Matkaajamme mielivät myös muistuttaa siitä oleellisesta seikasta, että gulag ei ole nykyVenäjällä mikään tabu, toisin kuin ajoittaisten hälyotsikoiden perusteella voisi ajatella. "Sorron tarinaa kertovat yksityiset ihmiset, kansalaisjärjestöt ja ortodoksikirkko", Ropponen ja Sutinen lausahtavat. "Joskus ne saavat siihen tukea, joskus niitä häiritään."

Tuoreemman leirikirjallisuuden ohella kaksikko lainaa toistuvasti Vankileirien saaristoa (Arhipelag GULAG, suom. ilm. 1974-1978), Solženitsynin pääosin 1960-luvulla laatimaa teossarjaa. Ehkä juuri sen eepoksen vaikutuksen alla he tekevät hillittyjä vertailuja natsileireihin, vertailuja, jotka takavuosina koettiin joissakin piireissä sopimattomiksi. Tässä yhteydessä täytyykin mainita Sutisen ja Silja Pitkäsen mainio matkakirja Kolmannen valtakunnan keskitysleirit (2014). "Näillä kahdella järjestelmällä oli kuitenkin ratkaisevia eroja, eikä niitä voi suoraan rinnastaa", Ropponen ja Sutinen tarkentavat.

Neuvostoleirit Solženitsyn toi tunnetulla tavalla julkisuuteen esikoisteoksellaan Ivan Denisovitšin päivä (Odin den Ivana Denisovitša, 1962). Kahden Villen kirjassa tuo kohukertomus esitellään hivenen harhauttavasti. Toisin kuin tekijät väittävät, Solženitsyn ei joutunut sensorin käskystä muokkaamaan lopetusta "myönteisempään" suuntaan. Yhtä omituinen on näkemys, jonka mukaan nimihenkilön "henkinen rakenne" murtuisi kertomuksen edetessä. Tutkimuksellinen konsensus (ja tekijän intentio) todistaa päinvastaista: Ivan Denisovitšin talonpoikainen neuvokkuus ei murene edes työleirin kurimuksessa.

Tuollainen kritiikki ei tietenkään vähennä Luiden tien arvoa kiehtovana matkakirjana ja neuvostoterrorin pätevänä kronikkana. Kun samalta firmalta on jo aiemmin ilmestynyt KlasGöran Karlssonin Vaino ja vaikeneminen (Terror och tystnad, 2010) sekä Stephen F. Cohenin Gulagista selvinneet (The Victims Return, 2013), Liken voidaan todeta ponnahtaneen leirikirjallisuuden johtavaksi kustantajaksi tässä maassa. Mutta missä viipyy kattava tutkimus tai tietokirja gulagin tuhansista suomalaisista vangeista? Heidän kohtaloihinsa Ropponen ja Sutinen kevyesti viittailevat. Vaikka Venäjän kaikkiin arkistoihin ei vieläkään olisi pääsyä, materiaalia luulisi kyllä karttuneen tuhtiin, kansallisesti mitä tärkeimpään kirjaan, joka kattaisi suurimman osan reaalisosialistisen naapurimme historiasta.

Erkki Vettenniemi

\title{
Suuret ajat vaativat suuria oppaita
}

\section{Rob Sears: Vladimir Putin - Menestyvän johtajan opetukset. Maailman mahtavimman miehen vinkit oman elämän valtiuteen. Helsin- ki: Aula \& Co, 2018. Suom. Anna Tuomikoski. 156 s. ISBN 978-952-7269-40-4.}

Elämäntaito-oppaat, eli "self-help" (tai "selfimprovement") -kirjallisuus, ovat melko vähän tutkittu ja ehkä myös hieman ylenkatsottu tietokirjallisuuden alalaji. Kyseessä on myös hyvin amerikkalaiseksi koettu genre. Pienen ihmisen pyrkimys onneen ja stressittömään elämään myönteisen ajattelun ja miksei ulkoisen menestyksenkin kautta kiteyttää toki jotain olennaista "amerikkalaisesta unelmasta". Yksi kaikkien aikojen kuuluisimmista oppaista on köyhästä farmarin pojasta uraauurtavaksi motivaatiokouluttajaksi nousseen Dale Carnegien teos Miten saan ystäviä, menestystä ja vaikutusvaltaa (How to Win Friends and Influence People, 1936, 
suom. 1939), josta otetaan jatkuvasti uusia painoksia - Suomessa viimeksi viime vuonna.

Itseapukirjallisuus on itse asiassa nykypäivänä todella suurta bisnestä. Se mahdollistaa jopa kokonaisen businessimperiumin ja tuoteperheen perustamisen, kuten vaikkapa Robert Kioysakin "Rich Dad" -franchise ja tämän vaimon Kim Kioysakin "Rich Woman" -spinoff. Oppaat ovat tehokas keino myös olemassaolevan brändin vakiinnuttamiseen. Jo kauan ennen presidenttiyttään Donald Trump kirjoitti toistakymmentä teosta, joista tunnetuin lienee muistelmaopaskirjayhdistelmä The Art of the Deal ("Diilin tekemisen taito", 1987).

Rob Sears on brittiläinen mainosmieskirjailija, jonka läpimurtoteos ratsasti pitkälti juuri Trumpin myyttisellä hahmolla ja nimellä. Se ei tosin ollut elämäntaidon opas, vaan jotain hieman erikoisempaa - nimittäin runoteos Donald Trumpin tviiteistä: The Beautiful Poetry of Donald Trump ("Donald Trumpin kaunista runoutta", 2017). Sears leikkeli Trumpin puheet ja tviitit lausefragmenteiksi, jotka sitten riimitteli temaattisiksi kokonaisuuksiksi loppusointuineen päivineen. Askarteluprojektin tuloksena syntyneet trumppilaiset runot nimeltä "I am the best" ja "Hot little high school girl" ilahduttivat huumorikirjallisuuden (ja miksei runoudenkin) ystäviä ympäri maailmaa.

Runokirjan menestyksen siivittämänä Sears on kuvittajaveljensä Tom Searsin kanssa tarttunut kiireen vilkkaa toisen suuren johtajan, Vladimir Putinin habitukseen ja pyrkinyt luomaan jotain hauskaa, innovatiivista ja myyvää tämän konseptin ympärille. Tuloksena on elämäntapaopasparodia Vladimir Putin: Menestyvän johtajan opetukset (Vladimir Putin: Life Coach), joka heti ilmestymisvuonnaan käännettiin ja julkaistiin myös suomeksi - oletettavasti aiheen ajateltiin puhuttelevan ja koskettavan jollain tavoin myös suomalaista lukijaa. Takakansiteksti lupaa, että kirja näyttää "miten samat manööverit joilla Putin nousi valtaan Kremlissä ja haastoi Yhdysvallat voivat auttaa ketä tahansa saamaan elämänsä todella nousuun".

Kirjan opetukset koostuvat 64:stä yleisestä elämänohjeesta, kuten esimerkiksi 'Palkkaa trolliarmeija", "Hanki oma koodinimi" ja "Tee alueliitoksia", jotka kontekstin tuntevalle tarjoavat vähintään lievää hymynkaretta suupieliin. Jokainen ohje sisältää kuvauksen Putiniin liittyvästä "faktasta", sekä kehystetyn neuvon, kuinka tavallinen lukija voi omassa elämässään soveltaa johtajan esimerkkiä ("Ole kuin Vlad"). Jokainen meistä voi vaikkapa laajentaa omaa aluettaan sangen helposti: "Jos esimerkiksi asut kerros- talossa, voit kaikessa hiljaisuudessa 'miehittää' yhteistilat ja julistaa naapureille, että ne kuuluvat esi-isiesi maahan" (s. 89). Ja jottei lukeminen käy ylivoimaiseksi, ohjeiden oheen on laadittu myös aiheeseen liittyvä tai sitä summaamaan pyrkivä pilapiirros kuvateksteineen.

Ajankohtaisuudestaan huolimatta yksi kirjan hauskimmista hetkistä löytyy kuitenkin hieman yllättäen viittauksesta poliittiseen historiaan ja Yhdysvaltain presidentin ja Putinin tapaamiseen vuonna 2001. Tapaamisesta vaikuttuneena ja ilahtuneena presidentti Bush alkoi kutsua venäläistä kollegaansa lempinimellä "Pootie Poot". Ja jos tätä ei usko, kirjasta löytyy lähdeviite The Guardianin 25.5.2002 päivättyyn uutiseen, joka on otsikoitu "Bush's love of Pootie Poot Putin". Anekdootti saa ensin nauramaan ja sitten hiljentymään: maailma on todella muuttunut paljon seitsemässätoista vuodessa - ja ei kuitenkaan tarpeeksi.

Kirja tarjoaa myös pieniä ripauksia Venäjään liittyvää reaalia-tietoutta kertomalla esimerkiksi, mitä on blat tai hieman modernimpi kompromat ("poliitikkoa tai julkisuuden henkilöä vahingoittava aineisto"). Lisäksi Sears ansioituu nostamalla esiin mielenkiintoisen, mutta sangen vähän tunnetun elokuvatapauksen nimeltä Epävirallinen suudelma (Potselui ne dlja pressy). Se kertoo romanttisen ja intiimin tarinan Tatjana-lentoemännän rakastumisesta Aleksandr Aleksandrovitš Platov -nimiseen poliitikkoon, josta tulee Venäjän presidentti. Elokuva on kuvattu jo 2000-luvun alussa, mutta jostain syystä se julkaistiin suoraan DVD:1lä vasta vuoden 2008 vaalien aattona.

Venäjä-ilmiöiden lisäksi kirja tutustuttaa lukijan myös muutamaan trendikkääseen angloamerikkalaisen maailman käsitteeseen. Manspreading on joillekin miehille luonteva tapa viedä tilaa liikennevälineissä tai kansainvälisissä poliitikoiden huipputapaamisissa istumalla jalat levällään. "Whataboutismi" puolestaan on sangen hyödyllinen retorinen keino, jolla vältetään itseen kohdistuva kritiikki vaihtamalla aihetta toiseen epäkohtaan: 'Jos joku sattuisi vaatimaan sinua tilille holtittomasta whataboutismistasi, sen kun vain muistutat, kuinka moni orjatyöläinen kuoli turhaan Kiinan muuria rakennettaessa" (s. 51).

Yksittäisistä hauskoista hetkistä ja oivalluksista huolimatta kirjan mekaanisesti toistuva rakenne (opetus - fakta - sovellus - pilakuva) on melko puuduttava. Ongelmaksi muodostuu myös se, että usein kuvat ja teksti tuntuvat kertovan kahta eri tarinaa, tai ainakaan ne eivät toimi täysin saumattomasti yhteen. Lisäksi yhtymäkohdat 
todellisiin elämäntaito-oppaisiin toteutuvat ehkä otsikkotasolla, mutta jäävät sangen pinnallisiksi. Näiden oppaiden suurena ystävänä olisin kaivannut jonkinlaista oivaltavampaa genren käsittelyä - edellytykset sille ainakin olisivat olleet lupaavat.

Teoksen perimmäinen ongelma on siinä, että "totuus" "suurista johtajista", Putinista tai vaikkapa Trumpista, on hauskempi, hurjempi ja absurdimpi kuin mikään väkinäinen hauskuuttamaan pyrkivä väännös siitä. Tämä kirja ei tuo mitään uutta tai oivaltavaa siihen kuvaan Putinista, joka meillä kaikilla "mutu"-tuntemuksella tuntuu jo olevan. Jokainen kadunmies ainakin Suomessa osaa ilman tätä kirjaakin kertoa näkemyksensä siitä, että Putin on ketku rikollinen, joka ei kaihda keinoja vallassa pysymiseen ja vallasta hyötymiseen. Tämä tarkoittaa, että kirjan poliittinen satiiri ei pure. Kirjan myötä Putin oikeastaan nouseekin esiin, ei naurunalaisena, vaan vain entistä myyttisempänä yli-ihmisenä.

Näin kirja ehkä puolivahingossa onnistuu nostamaan esiin myös taustalla piilevän varsinaisen ongelman: jos humoristiseksi tarkoitettu kirja päätyykin toistamaan vain sen saman Putin-legendan jota media tuuttaa jo muutenkin joka tuutista, niin mitä se silloin kertoo mediasta ja sen tavasta kertoa asioita? Ilmiöt tuntuvat muuttuvan karikatyyreiksi itsestään jo kauan ennen kuin päätyvät huumorikirjallisuuden riepoteltavaksi. Mediaan kohdistuvan kritiikin ajatusta tukevat myös faktaosioihin upotetut runsaat lähdeviitteet: kirjan lähteinä on pääosin käytetty englanninkielisen maailman mediatekstejä. Jos terävimmän pilkan kohteeksi onkin tarkoitettu läntinen media, niin ongelmaksi muodostuu se, että asioiden pohtiminen tällä tasolla ei olekaan enää hauskaa, vaan pikemminkin ahdistavaa ja huolestuttavaa.
Oli parodian kohteena sitten nykypolitiikka, median toimintatavat tai elämäntaito-oppaat, Searsin kirja jää kaikkien käsittelemiensä ilmiöiden varjoon. Niiden keskinäisten yhteyksien esiin nostaminen edes alustavasti on silti hyödyllinen ja mielenkiintoinen teko. Yhteyksien jatkokäsittelyllä voisi olla potentiaalia tarjota työkaluja populistisen mielikuva- ja tunnepoliitikan strategioiden purkamiseen laajemminkin. "Sen minkä sanot todeksi - siitä tulee totta - se on ehkä uskomatonta mutta näin se on" on keskeinen sanoma Jen Sinceron vuoden 2013 menestyskirjassa You Are a Badass: How to Stop Doubting Your Greatness and Start Living an Awesome Life (Suom. You Are A Badass Lopeta itsesi vähättely ja elä täysillä, 2017). Totuudenjälkeinen aika ja myönteisen ajattelun voima tukeutuvat molemmat assertiivisen sanan mahtiin: todellisuus muotoutuu vain sanojen, sanavalintojen ja väittämien kautta, jotka muuttuvat todeksi kun niistä pitää tarpeeksi pitkään kiinni - niin hyvässä kuin pahassa.

Vladimir Putin: Menestyvän johtajan opetukset-kirjan konsepti on ollut varmasti ideatasolla helppo myydä kustantajalle, sillä siinä yhdistyy niin moni ajallemme tyypillinen ja herkullinen piirre. Toteutus kuitenkin on - ehkä kiireen alla jäänyt vain roiskaisuksi sinne päin. Kirjan paras anti on se, että se pakottaa miettimään rajoja toden ja valheen, liioittelun ja neutraalin esityksen välillä. Lisäksi kirjan kansi on yksinkertaisesti upea: Putin photoshopattuna leikkisän rentona ikkunalaudalle istuskelemaan. Jo pelkästään sen nähdäkseen kirja kannattaa ottaa ainakin kerran käteensä.

Ira Österberg 